\title{
Asexual Propagation of Sheanut Tree (Vitellaria paradoxa C.F. Gaertn.) Using a Container Layering Technique
}

\author{
Naalamle Amissah ${ }^{1 *}$, Brain Akakpo ${ }^{1}$, Julius Yeboah $^{2}$, Essie Blay ${ }^{1}$ \\ ${ }^{1}$ Department of Crop Science, College of Agriculture and Consumer Sciences, University of Ghana, Accra, Ghana; ${ }^{2}$ Cocoa Research \\ Institute of Ghana (CRIG), Bole, Ghana. \\ Email: *naalamle@gmail.com
}

Received July $5^{\text {th }}$, 2013; revised August $5^{\text {th }}, 2013$; accepted August 25 ${ }^{\text {th }}, 2013$

Copyright (c) 2013 Naalamle Amissah et al. This is an open access article distributed under the Creative Commons Attribution License, which permits unrestricted use, distribution, and reproduction in any medium, provided the original work is properly cited.

\begin{abstract}
In spite of the economic potential of the sheanut tree (Vitellaria paradoxa), its domestication still has not been achieved due to the long juvenile period of seed propagated plants and the absence of a reliable vegetative propagation method. Three experiments were conducted by using a modified container layering technique to investigate the effects of season (rainy and dry season), light treatments (etiolation and natural light) and indole 3-butyric acid (IBA) on root formation in juvenile and mature sheanut trees. The effect of light treatments on the internal conditions such as level of sugars (soluble, insoluble and total sugars) and total free phenols in layered sheanut shoots was also considered. Rooting was generally lower in the mature trees (27.9\%) compared to that in juvenile 4 year-old plants (40.9\%). Etiolation increased the levels of total sugars and phenols in shoots of 4-year-old plants and mature fruit bearing trees, but this increase did not significantly enhance rooting in both the juvenile and mature sheanut trees. The container layering technique holds promise as a method for the asexual propagation of sheanut planting material. Roots formed using this method looked healthy and were vertically orientated giving layered shoots a better chance at survival.
\end{abstract}

Keywords: Etiolation; Container Layering Technique; Indolebutyric Acid; Sheanut Tree

\section{Introduction}

Vitellaria paradoxa C.F. Gaertn (the sheanut tree) is a deciduous tree native to Tropical Africa and said to be indigenous to the Guinea and Sudan Savanna zone [1]. Shea butter, a product of its nut, is the main source of livelihood in the Northern regions of Ghana with the potential to alleviate rural poverty in these areas [2]. Shea butter has anti-microbial properties and as such is widely used locally in herbal medicine preparations as well as in the pharmaceutical and cosmetic industries $[3,4]$. Despite the social and economic importance of the sheanut tree, its tree populations are in the wild and domestication is still a challenge due to the absence of a reliable propagation technique. Propagation from seed, which is the current method used, is difficult, as seeds are recalcitrant and have been found to lose viability shortly after harvest [1]. Where seedlings are produced, they possess a characteristic strong taproot system and do not transplant well.

Vegetative propagation methods such as stem cuttings and airlayering have also proved unreliable [5-10]. There

*Corresponding author. are reports of grafting having been used successfully on field plants [11]. However, grafting can only be used on already established fields. There is therefore the need to develop a reliable asexual propagation technique that would supply rootstock material to help with the domestication of sheanut trees. This research seeks to combine the use of practices and pre-treatments that have been shown to enhance rooting in woody plants in conjunction with a container layering technique. Practices such as coppicing or severe pruning of tree crowns [12,13], etiolation [14-17], and use of plant growth regulators such as Gibberellic acid $\left(\mathrm{GA}_{3}\right)$ and Indole butyric acid (IBA) [12] have been found to enhance rooting of mature difficultto-root woody plant species.

The proposed container layering technique is one, in which layered shoots arising from the juvenile portion of the plant are rooted while still attached to the parent plant. Frolich [18] was the first to use this method in the propagation of avocardo varieties. Subsequently, the technique has been modified and used successfully in the propagation of oak (Quercus spp.) shoots [17,19-21]. The objective of this study was to develop a reliable vegeta- 
tive propagation technique for the multiplication of planting material for domestication purposes by using the combined effects of etiolation and Indole 3-butyric acid.

\section{Materials and Methods}

Three experiments were carried out on juvenile 4-yearold and mature fruit bearing trees using a container layering technique (CLT) at the Cocoa Research Institute of Ghana-Bole Substation in the Northern Region from September 2009 to October 2010. The technique used was a modification of that used on Quercus sp [21].

\subsection{Effect of Light and IBA Treatments on Rooting in Layered Juvenile Shea Trees during the Dry Season (October 2009 to February 2010)}

Four-year-old shea plants in polythene bags were cut back leaving a $4 \mathrm{~cm}$ stump above soil level and allowed to break bud. Upon budbreak fifty percent of the seedlings were etiolated by placing $15.2 \mathrm{~cm}$ (diameter) PVC pipes of height $15 \mathrm{~cm}$ over the cut back stumps for 14 days. The PVC pipes were pushed into the soil in the poly bags to hold the pipes in place and covered with aluminum foil to exclude light from the setup thus creating an ideal dark environment $\left[0.00 \mu \mathrm{mol} / \mathrm{m}^{2} / \mathrm{sec}\right.$ for photosynthetically active radiation (PAR)]. The other 50\% were grown in natural light. A $2 \times 2$ factorial experiment (2 IBA levels $\times 2$ light levels) was used with each hormone-light combination represented by 25 plants. A completely randomized design was used with three replications.

When shoots reached a height of 8 - $10 \mathrm{~cm}$ seedlings in each treatment group had their basal $4 \mathrm{~cm}$ section painted with a solution of $8000 \mathrm{ppm}$ or 10,000 ppm Indole butyric acid (IBA) dissolved in 95\% ethanol. After the IBA solution dried, cut PVC pipes were placed over the plants and the treated section of the shoots covered with a 2:1 (v/v) moist sterile rice-husk: sand mix. The shoots in the etiolated treatments were then weaned to light (greened) by making holes in the aluminum foil covering the top section of the PVC pipes, to introduce light gradually into the setup. The aluminum foil was removed after greening of the shoots, by the seventh day, and subsequently, the shoots were allowed to grow in natural light. Routine root inspection was done on three randomly selected stock plants per treatment to ascertain the level of root formation. The experiment was setup beneath $50 \%$ shade.The treatments in the dry season (October 2009 to February 2010) experiment did not include a control (with a no IBA treatment). Previous studies conducted on sheanut at the research station showed poor rooting $(1 \%)$ without the use of rooting hormones $[8,9]$.

\subsection{Effect of Light and IBA Treatments on Rooting in Layered Juvenile Shea Trees during the Rainy Season (June 2010 to September 2010)}

The experiment was repeated in the rainy season (June to September 2010) using 4-year-old and mature bearing trees. For the 4-year-old trees, six (6) treatment combinations made up of IBA at $8000 \mathrm{ppm}$ and 10,000 ppm and two light regimes (natural and etiolated) in a completely randomized design (CRD) was used with three replications. Each treatment combination was represented by 20 plants per replicate. Layered propagules from experiments 1 and 2 were evaluated for rooting 10 weeks after IBA treatment (Figure 1(a)).

Shoots were considered rooted when they possessed at least one root measuring not less than $1 \mathrm{~cm}$. The setup was the same as in the dry season experiment.

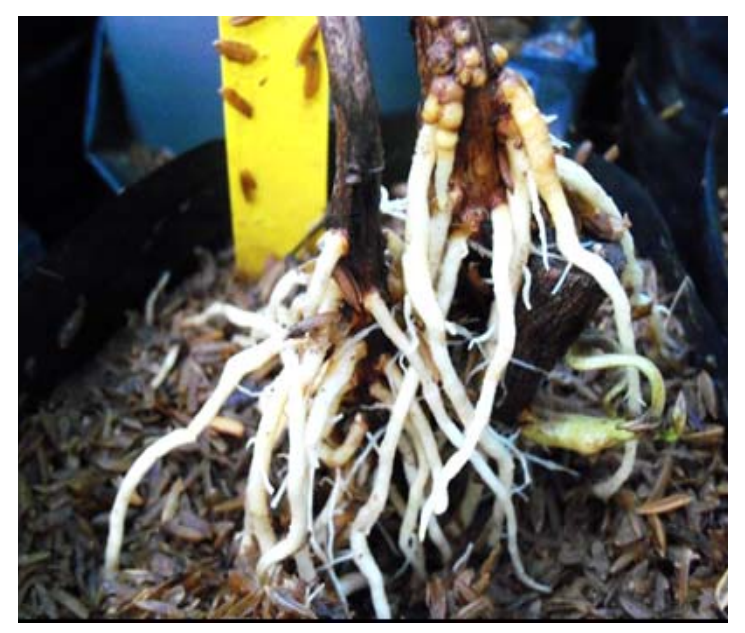

(a)

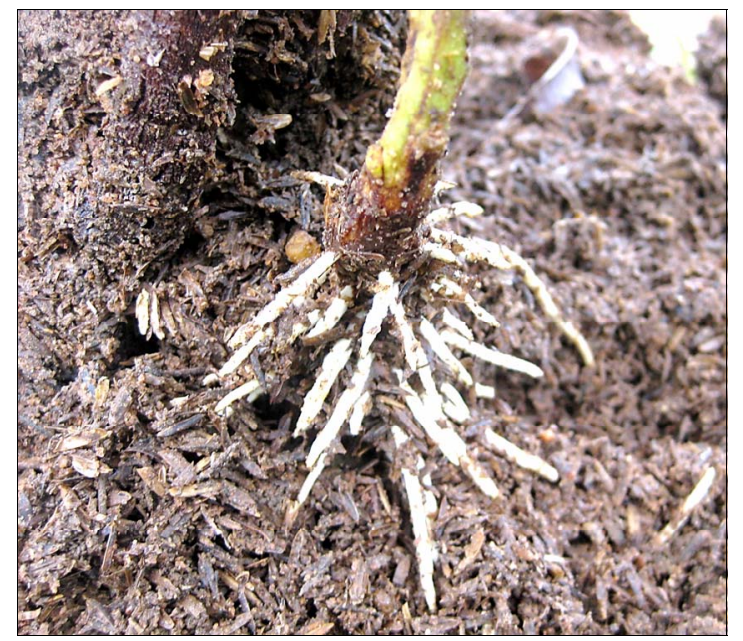

(b)

Figure 1. (a) Rooted 4-year-old and (b) mature sheanut shoots still attached to the stock plant, approximately ten weeks after treating with IBA. 


\subsection{Effect of Light and IBA Treatments on Rooting in Layered Mature Shea Trees during the Rainy Season (June 2010 to September 2010)}

With the mature fruit bearing trees the same treatment combinations of IBA and light regimes as in experiment 2 was used. However, etiolation was achieved by placing a bottomless bucket $(26 \mathrm{~cm}$ in diameter and $32 \mathrm{~cm}$ in height) over the cutback stump. The open end of each bucket was covered with aluminum foil, and the aluminum foil held in place with elastic bands. There were 10 trees per treatment replicate (three replicates). Layered propagules were evaluated for rooting 10 weeks after IBA treatment (Figure 1(b)).

\subsection{Data Collection and Statistical Analysis}

Two (2) shoots were taken before IBA treatment from each replicate and bulked per treatment for each of the three layering experiments. The samples were analyzed according to $[22,23]$ for sugars and phenols respectively. Data collected at the end of the ten week rooting process were percentage rooting per treatment, number of roots per rooted shoot (NRPS) and length of the longest root per rooted shoot (LLR).

Data collected were analyzed using ANOVA in GENSTAT (Release 11.1). The Least Significant Difference (LSD) was used to determine differences among the means for the main effects.

\section{Results and Discussion}

\subsection{Effect of Light and IBA Treatments on Rooting in Layered Juvenilesheanut Plants during the Dry and Rainy Seasons}

Light and indole 3-butyric acid (IBA) treatments had no significant effect on rooting, number of roots per shoot (NRPS) and the length of the longest root (LLR) in shoots of 4-year-old plants during the dry season experiment (Table 1).

In experiment 2, light and IBA treatments significantly $(\mathrm{p}<0.05)$ affected rooting. Shoots grown in light and treated with 10,000 ppm IBA (SRL ${ }_{10000}$ ) gave the highest rooting percentage of 53.3\% (Table 2). In this experiment, light treatment $\left(\mathrm{SRL}_{10000}\right)$ gave a significantly $(\mathrm{p}<$ 0.05 ) higher rooting percentage when compared with the etiolated treatments $\left[\mathrm{SRE}_{10000}(35.7 \%)\right.$ and $\mathrm{SRE}_{8000}$ (30.9\%)]. This experiment agreed with findings by [17] that etiolation did not play a significant role in the rooting of Quercus bicolor layered shoots even though it significantly enhanced rooting in cuttings. The control treatments (no IBA) did not produce any roots, confirming results on the importance of rooting hormones in promoting adventitious root formation in sheanut $[8,10]$.
Table 1. Effect of light and indole 3-butyric acid treatments on rooting, number of roots per layered shoot and the length of the longest root in 4-year-old sheanut plants during the dry season.

\begin{tabular}{cccc}
\hline Treatment & \% Rooting & NRPS & LLR (cm) \\
\hline SDL $_{8000}$ & $40.2 \pm 9.1 \mathrm{a}$ & $10 \pm 1.6 \mathrm{a}$ & $7.6 \pm 3.3 \mathrm{a}$ \\
SDE $_{8000}$ & $52.3 \pm 3.8 \mathrm{a}$ & $9 \pm 1.2 \mathrm{a}$ & $6.4 \pm 1.6 \mathrm{a}$ \\
SDL $_{\mathbf{1 0 0 0 0}}$ & $56.8 \pm 6.5 \mathrm{a}$ & $7 \pm 1.9 \mathrm{a}$ & $8.5 \pm 0.4 \mathrm{a}$ \\
SDE $_{10000}$ & $46.1 \pm 5.9 \mathrm{a}$ & $6 \pm 0.6 \mathrm{a}$ & $5.7 \pm 1.2 \mathrm{a}$ \\
\hline
\end{tabular}

Data represent means \pm S.E of three replicates. Means with different letters are significantly different at $\mathrm{p}<0.05$. NRPS - number of roots per shoot, LLR — length of the longest root, $\mathbf{S D L}_{\mathbf{8 0 0 0}}$ \& $\mathbf{S D L}_{\mathbf{1 0 0 0 0}}$-layered light-grown shoots during the dry season, $\mathbf{S D E}_{\mathbf{8 0 0 0}} \& \mathrm{SDE}_{\mathbf{1 0 0 0 0}}$-layered etiolated shoots during the dry season. Numerical subscripts refer to concentrations of IBA in ppm.

Table 2. Effect of light and indole-3 butyric acid treatments on rooting, number of roots and length of the longest root in 4-year-old sheanut plants during the rainy season.

\begin{tabular}{cccc}
\hline Treatment & \% Rooting & NRPS & LLR (cm) \\
\hline SRL $_{\mathbf{0}}$ (Ctrl) & $0 \pm 0.0 \mathrm{a}$ & $0 \pm 0.0 \mathrm{a}$ & $0 \pm 0.0 \mathrm{a}$ \\
$\mathbf{S R E}_{\mathbf{0}}$ (Ctrl) & $0 \pm 0.0 \mathrm{a}$ & $0 \pm 0.0 \mathrm{a}$ & $0 \pm 0.0 \mathrm{a}$ \\
SRL $_{\mathbf{8 0 0 0}}$ & $43.6 \pm 6.3 \mathrm{bc}$ & $5.0 \pm 0.6 \mathrm{~b}$ & $3.9 \pm 0.7 \mathrm{bc}$ \\
SRE $_{\mathbf{8 0 0 0}}$ & $30.9 \pm 6.7 \mathrm{~b}$ & $5.0 \pm 1.0 \mathrm{~b}$ & $2.9 \pm 0.5 \mathrm{~b}$ \\
SRL $_{10000}$ & $53.3 \pm 4.5 \mathrm{c}$ & $6.0 \pm 0.7 \mathrm{~b}$ & $4.1 \pm 0.2 \mathrm{bc}$ \\
$\mathbf{S R E}_{10000}$ & $35.7 \pm 6.7 \mathrm{~b}$ & $5.0 \pm 0.7 \mathrm{~b}$ & $4.3 \pm 0.7 \mathrm{c}$ \\
\hline
\end{tabular}

Data represent means \pm S.E of three replicates. Means with different letters are significantly different at $\mathrm{p}<0.05$. NRPS - number of roots per shoot, LLR - length of the longest root, $\mathbf{S R L}_{\mathbf{8 0 0 0}} \mathbf{\&}_{\mathbf{S R}} \mathbf{S R}_{\mathbf{1 0 0 0}}$ - layered light-grown seedlings during the rainy season, $\mathbf{S R E}_{\mathbf{8 0 0 0}} \boldsymbol{\&} \mathbf{S R E}_{\mathbf{1 0 0 0 0}}$-layered etiolated seedlings during the rainy season. Numerical subscripts refer to concentrations of IBA in ppm.

Contrary to expectation variability in rooting was not pronounced between the two seasons (Experiment 1 and 2).

\subsection{Effect of Light and IBA Treatments on Rooting in Layered Juvenile Sheanut Plants during the Dry and Rainy Seasons}

Shoots not treated with IBA did not form roots as observed in Experiment $1 \& 2$. Results from experiment 3 showed significant $(\mathrm{p}<0.05)$ differences between the treatments. Rooting was highest in the $\mathrm{ME}_{10000}$ treatment (37.7\%) and lowest in the $\mathrm{ME}_{8000}(15.3 \%)$. The number of roots per shoot (NRPS) was not significantly ( $<<0.05$ ) different among the treatments. Length of the longest root on the other hand was significantly different among treatments, with $\mathrm{ME}_{10000}$ treatment having the longest LLR $(4.4 \mathrm{~cm})$ (Table 3) an indication that root formation took place earlier. 
Comparing the results of experiment 3 with those of experiment 2 (carried out in the rainy season) a significant $(\mathrm{p}<0.05)$ difference was found between the rooting performance of layered shoots from mature trees and that of 4-year-old plants. The average rooting percentages for the 4-year-old plants was $40.3 \%$ while that of mature trees was 27.9\% (Table 4).

Table 3. Effect of light and IBA treatments on rooting in layered stems of mature sheanut trees during the rainy season.

\begin{tabular}{cccc}
\hline Treatment & \% Rooting & NRPS & LLR (cm) \\
\hline $\mathbf{M L}_{\mathbf{0}}$ (Ctrl) & $0 \pm 0.0 \mathrm{a}$ & $0 \pm 0.0 \mathrm{a}$ & $0 \pm 0.0 \mathrm{a}$ \\
$\mathbf{M E}_{\mathbf{0}}$ (Ctrl) & $0 \pm 0.0 \mathrm{a}$ & $0 \pm 0.0 \mathrm{a}$ & $0 \pm 0.0 \mathrm{a}$ \\
$\mathbf{M L}_{\mathbf{8 0 0 0}}$ & $35.1 \pm 7.3 \mathrm{bc}$ & $5.0 \pm 1.0 \mathrm{~b}$ & $3.2 \pm 0.2 \mathrm{~b}$ \\
$\mathbf{M E}_{\mathbf{8 0 0 0}}$ & $15.3 \pm 3.3 \mathrm{~b}$ & $3.0 \pm 0.5 \mathrm{~b}$ & $2.9 \pm 0.1 \mathrm{~b}$ \\
$\mathbf{M L}_{\mathbf{1 0 0 0 0}}$ & $23.6 \pm 7.4 \mathrm{bc}$ & $5.0 \pm 1.3 \mathrm{~b}$ & $4.4 \pm 0.4 \mathrm{c}$ \\
$\mathbf{M E}_{\mathbf{1 0 0 0 0}}$ & $37.7 \pm 9.6 \mathrm{~b}$ & $4.0 \pm 0.1 \mathrm{~b}$ & $3.3 \pm 0.6 \mathrm{~b}$ \\
\hline
\end{tabular}

All data represent means \pm S.E of three replicates. Means with different letters are significantly different at $\mathrm{p}<0.05$. NRPS - number of roots per shoot, LLR - length of the longest root, $\mathbf{M L}_{\mathbf{8 0 0 0}} \mathbf{\&} \mathbf{M L}_{\mathbf{1 0 0 0 0}}$-layered lightgrown shoots of mature sheanut trees, $\mathbf{M E}_{\mathbf{8 0 0 0}} \mathbf{\&} \mathbf{M E}_{\mathbf{1 0 0 0 0}}$-layered etiolated shoots of mature sheanut trees. Numerical subscripts refer to concentrations of IBA in ppm.

Table 4. Effect of light and IBA treatments on rooting in layered stems of sheanut plants and mature trees.

\begin{tabular}{cccc}
\hline Treatment & \% Rooting & NRPS & LLR (cm) \\
\hline SRL $_{\mathbf{0}}(\mathbf{C t r l})$ & $0 \pm 0.0 \mathrm{a}$ & $0 \pm 0.0 \mathrm{a}$ & $0 \pm 0.0 \mathrm{a}$ \\
SRE $_{\mathbf{0}}(\mathbf{C t r l})$ & $0 \pm 0.0 \mathrm{a}$ & $0 \pm 0.0 \mathrm{a}$ & $0 \pm 0.0 \mathrm{a}$ \\
SRL $_{\mathbf{8 0 0 0}}$ & $43.6 \pm 6.3 \mathrm{~cd}$ & $5.0 \pm 0.6 \mathrm{~cd}$ & $3.9 \pm 0.7 \mathrm{~b}$ \\
SRE $_{\mathbf{8 0 0 0}}$ & $30.9 \pm 6.7 \mathrm{~cd}$ & $5.0 \pm 1.0 \mathrm{~cd}$ & $2.9 \pm 0.5 \mathrm{~b}$ \\
SRL $_{\mathbf{1 0 0 0 0}}$ & $53.3 \pm 4.5 \mathrm{~d}$ & $6.0 \pm 0.7 \mathrm{~d}$ & $4.1 \pm 0.2 \mathrm{~b}$ \\
SRE $_{\mathbf{1 0 0 0 0}}$ & $35.7 \pm 6.7 \mathrm{c}$ & $5.0 \pm 0.7 \mathrm{~cd}$ & $4.3 \pm 0.7 \mathrm{~b}$ \\
ML $_{\mathbf{0}}(\mathbf{C t r l})$ & $0 \pm 0.0 \mathrm{a}$ & $0 \pm 0.0 \mathrm{a}$ & $0 \pm 0.0 \mathrm{a}$ \\
$\mathbf{M E}_{\mathbf{0}}(\mathbf{C t r l})$ & $0 \pm 0.0 \mathrm{a}$ & $0 \pm 0.0 \mathrm{a}$ & $0 \pm 0.0 \mathrm{a}$ \\
$\mathbf{M L}_{\mathbf{8 0 0 0}}$ & $35.1 \pm 7.3 \mathrm{c}$ & $5.0 \pm 1.0 \mathrm{~cd}$ & $3.2 \pm 0.2 \mathrm{~b}$ \\
$\mathbf{M E}_{\mathbf{8 0 0 0}}$ & $15.3 \pm 3.3 \mathrm{ab}$ & $3.0 \pm 0.5 \mathrm{c}$ & $2.9 \pm 0.1 \mathrm{~b}$ \\
ML $_{\mathbf{1 0 0 0 0}}$ & $23.6 \pm 7.4 \mathrm{bc}$ & $5.0 \pm 1.3 \mathrm{~d}$ & $4.4 \pm 0.4 \mathrm{~b}$ \\
ME $_{\mathbf{1 0 0 0 0}}$ & $37.7 \pm 9.6 \mathrm{~cd}$ & $4.0 \pm 0.1 \mathrm{bc}$ & $3.3 \pm 0.6 \mathrm{~b}$ \\
\hline
\end{tabular}

All data represent means \pm S.E of three replicates. Means with different letters are significantly different at $\mathrm{p}<0.05$. NRPS - number of roots per shoot, LLR - length of the longest root, SRL $\mathbf{8 0 0 0}_{\mathbf{8 0}}$ \& $\mathbf{S R L}_{\mathbf{1 0 0 0}}$-layered light-grown seedlings during the rainy season, $\mathbf{S R E}_{\mathbf{8 0 0 0}} \boldsymbol{\&}_{\mathbf{S R E}} \mathrm{SR000}_{\mathbf{1 0 0}}$-layered etiolated seedlings during the rainy season, $\mathbf{M L}_{\mathbf{8 0 0 0}} \& \mathbf{M L}_{\mathbf{1 0 0 0 0}}$-layered light-grown shoots of mature shea trees, $\mathbf{M E}_{\mathbf{8 0 0 0}} \mathbf{\&} \mathbf{M E}_{\mathbf{1 0 0 0 0}}$-layered etiolated shoots of mature shea trees. Numerical subscripts refer to concentrations of IBA in ppm.
This difference in rooting may be due to the difference in age and size (thickness) of shoots being treated. Shoots that developed from the mature cutback trees were observed to be vigorous growing, bigger and thicker than those from the 4-year-old plants and may have required a higher IBA concentration to be more effective in root formation. A combination of using other IBA solvents (methanol and acetone) and higher concentrations of rooting hormones may have enhanced rooting in shoots of mature plants.

Number of roots per shoots (NRPS) between treatments were also significantly $(\mathrm{p}<0.05)$ different. Length of the longest root (LLR) on the other hand did not differ significantly between treatments (Table 4). The differences in the rooting percentages might be due to sensitiveity of the shoot tissues to IBA penetration. Shoot growth in the cutback mature trees was observed to be more vigorous than in the 4-year-old plants.

\subsection{Effect of Light and IBA Treatments on Rooting in Layered Juvenile Sheanut Plants during the Dry and Rainy Seasons}

Light treatments also had no significant effect on the levels of sugars and total free phenols (TFP) in layered shoots during the dry season (Table 5).

Similar trends were found in layered shoots during the rainy season except the total free phenols were 1.7 times higher in etiolated shoots than in shoots grown in ambient light prior to IBA treatment (Table 6).

Light levels had a significant $(\mathrm{p}<0.05)$ effect on soluble sugars in shoots from mature sheanut trees (Table 7). Etiolated shoots contained higher soluble sugars (123.4 $\mathrm{mg} / \mathrm{g})$ than light grown shoots $(81.3 \mathrm{mg} / \mathrm{g})$. Light treatments had no significant effect on the levels of insoluble sugars and total free phenols.

These findings were also contrary to those by [10] who found increased rooting in sheanut cuttings that had high levels of phenols. The differences in phenols did not enhance rooting as found by [24], who reported higher rooting percentages in Pinus cuttings treated with auxin, which resulted in lower phenolic acid contents. This did not also confirm the suggestion by [25] that propagules with high total phenol content had higher amounts of ortho-dihydroxyphenols, which decreased IAA-oxidase activity, increasing the concentration of endogenous IAA thereby increasing rooting. Findings from the current experiment were also contrary to those of [10] who observed higher rooting percentages in cuttings of sheanut plants that contain high level of phenols. It is possible that the effect of the phenols, although high in the layered experiment may not have significantly influenced rooting because their effect was masked by the shoots being attached to the parent plant unlike in cuttings where 
Table 5. Effect of light treatments on the levels of soluble, insoluble, total sugars and total free phenols in shoots of 4-year-old sheanut plants during the dry season.

\begin{tabular}{ccccc}
\hline \multirow{2}{*}{ Treatments } & \multicolumn{3}{c}{ Sugars $(\mathbf{m g} / \mathbf{g})$} & \multirow{2}{*}{ Total free phenols $(\mathbf{m g} / \mathbf{g})$} \\
\cline { 2 - 4 } & Soluble & Insoluble & Total & $5.5 \pm 1.7 \mathrm{a}$ \\
Etiolated & $66.2 \pm 2.2 \mathrm{a}$ & $16.8 \pm 1.9 \mathrm{a}$ & $83.0 \pm 3.9 \mathrm{a}$ & $8.9 \pm 0.5 \mathrm{a}$ \\
\hline
\end{tabular}

Data represent means \pm S.E of six replicates. Means with different letters are significantly different at $\mathrm{p}<0.05$.

Table 6. Effect of light treatments on sugars and total free phenols in shoots of 4-year-old sheanut plants during the rainy season.

\begin{tabular}{ccccc}
\hline \multirow{2}{*}{ Treatments } & \multicolumn{3}{c}{ Sugars $(\mathbf{m g} / \mathbf{g})$} & \multirow{2}{*}{ Total free phenols $(\mathbf{m g} / \mathbf{g})$} \\
\cline { 2 - 4 } & Soluble & Insoluble & Total & $40.5 \pm 1.7 \mathrm{a}$ \\
\hline \multirow{2}{*}{ Etiolated } & $183 \pm 2.2 \mathrm{a}$ & $20.4 \pm 1.9 \mathrm{a}$ & $204 \pm 3.9 \mathrm{a}$ & $24.2 \pm 0.5 \mathrm{~b}$ \\
\hline
\end{tabular}

Data represent means $( \pm$ S.E) of six replicates. Means with different letters are significantly different at $\mathrm{p}<0.05$.

Table 7. Effect of light treatments on the level of sugars and total free phenols in shoots of cutback mature shea trees.

\begin{tabular}{ccccc}
\hline \multirow{2}{*}{ Treatments } & \multicolumn{3}{c}{ Sugars $(\mathbf{m g} / \mathbf{g})$} & \multirow{2}{*}{ Total free phenols $(\mathbf{m g} / \mathbf{g})$} \\
\cline { 2 - 4 } & Soluble & Insoluble & Total & $25 \pm 4.1 \mathrm{a}$ \\
\hline Etiolated & $123.4 \pm 17.8 \mathrm{a}$ & $19.0 \pm 1.8 \mathrm{a}$ & $142.4 \pm 29.6 \mathrm{a}$ & $26.8 \pm 0.8 \mathrm{a}$ \\
\hline
\end{tabular}

Data represent means \pm S.E of six replicates. Means with different letters are significantly different at $\mathrm{p}<0.05$.

Table 8. Effect of light treatments on the levels of sugars and total free phenols in shoots of cutback shea during the dry and the rainy season.

\begin{tabular}{ccccc}
\hline \multirow{2}{*}{ Treatments } & \multicolumn{3}{c}{ Sugars $(\mathbf{m g} / \mathbf{g})$} & \multirow{2}{*}{ Total free phenols (mg/g) } \\
\cline { 2 - 4 } & Soluble & Insoluble & Total & $8.9 \pm 0.5 \mathrm{c}$ \\
\hline DL & $57.3 \pm 2.7 \mathrm{~b}$ & $13.9 \pm 0.7 \mathrm{~d}$ & $71.2 \pm 2.2 \mathrm{~b}$ & $5.5 \pm 1.66 \mathrm{c}$ \\
DE & $66.2 \pm 2.2 \mathrm{~b}$ & $16.8 \pm 1.9 \mathrm{c}$ & $83.0 \pm 3.9 \mathrm{~b}$ & $28.3 \pm 5.1 \mathrm{~b}$ \\
RL & $190.0 \pm 25.3 \mathrm{a}$ & $25.5 \pm 0.8 \mathrm{a}$ & $215.5 \pm 25.2 \mathrm{a}$ & $43.5 \pm 7.8 \mathrm{a}$ \\
\hline
\end{tabular}

All data represent means $( \pm$ S.E) of four replicates without the control treatment. Means with different letters are significantly different at $\mathrm{p}<0.05$. DL-Light treated shoots in the dry season, DE_-Etiolated shoots in the dry season, $\mathbf{R L}$ - Light treated shoots in the rainy season and $\mathbf{R E}$-Etiolated shoots in the rainy season.

shoots are severed from the parent plant and rooted in a medium.

Comparing the two seasons in the 4-year-old plants, light treatments had a significant effect on the levels of sugars and total free phenols between the two seasons (dry and rainy). The levels of soluble, insoluble, total sugars and total free phenols in shoots of cutback sheanut plants were approximately three times higher in the rainy season than in the dry season (Table 8). This observation may be explained on the basis of seasonal effect as sea- sonal patterns are important for root initiation and development on stems during layering [13].

\subsection{Effect of Light Treatments on the Levels of Sugars and Total Free Phenols in Shoots of Mature Fruit Bearing Trees during the Rainy Season}

Comparing rooting in the juvenile and mature plants during the rainy season (data not shown), the rooting performance of 4-year-old sheanut plants were on aver- 
age higher $(40.9 \%)$ than in the mature plants $(27.9 \%)$. Etiolation did not enhance adventitious root formation but played a role in increasing the levels of total sugars and total free phenols (TFP) in the shoots.

\section{Conclusion}

The container layering technique (CLT) holds promise for the rooting of sheanut trees. Roots formed using the CLT technique looked healthier. They were more in number and had a vertical orientation giving the propagules had a better chance at survival, compared to earlier attempts at the CRIG, Bole Research Substation, where cuttings formed 1 - 2 roots that were brittle and had more of a horizontal orientation and thus affected the chances of the plants survival. Further studies would need to be conducted to investigate the effects of auxins concentrations, combinations and timing of treatment on rooting.

\section{Acknowledgements}

The authors wish to acknowledge Cocoa Research Institute of Ghana (CRIG), Bole Substation in Northern Ghana for providing the plant material used for the project.

\section{REFERENCES}

[1] A. Nikiema and B. E. Umali, "Vitellaria paradoxa C.F. Gaertn. [Internet] Record from Protabase,” In: H. A. M. van der Vossen and G. S. Mkamilo, Eds, PROTA (Plant Resources of Tropical Africa, Wageningen, 2007. http://database.prota.org/search.htm

[2] F. R. Irvine, "Woody Plants of Ghana with Special Reference to Their Uses," Oxford University Press, London, 1961.

[3] J. N. Fobil, "Research and Development of the Shea Tree and Its Products," 2008. www.solution.site.org/artman

[4] J. B. Hall, D. P. Aebischer, H. F. Tomlinson, E. OseiAmaning and J. R. Hindle, "Vitellariaparadoxa, a Monograph, Project B4850,” Forestry Research Progaramme, School of Agricultural Sciences, University of Wales, Bangor, 1996, p. 105.

[5] A. Grolleau, “Contribution Al'Etude de la Multiplication Vegetative par Greffage du Karité (Vitellaria paradoxa Gaertn. f. = Butryospermum paradoxum Hepper)," Bois et Forets des Tropiques, No. 222, 1989, pp. 38-40.

[6] Z. Teklehaimanot, H. Tomlinson, T. Lemma and K. Reeves, "Vegetative Propagation of Parkiabiglobosa (Jacq.) Benth, an Undomesticated Fruit Tree from West Africa," Journal of Horticulture Science, No. 71, 1996, pp. 205215.

[7] P. N. Lovett and N. Haq, "Evidence for Anthropic Domestication of the Sheanut Tree (Vitellaria paradoxa)," Agroforest System, No. 48, 2000, pp. 273-288.

[8] K. Opoku-Ameyaw, F. M. Amoah and J. Yeboah, "Studies into Vegetative Propagation on the Sheanut Tree (Vitellaria paradoxa Gaertn),” Journal of Ghana Science Association, Vol. 4, No. 2, 2002, pp. 138-145.

[9] H. Sanou, S. Kambou, Z. Teklehaimanot, M. Dembele, H. Yossi, S. Sina and L. Djingdia, "Vegetative Propagation of Vitellaria paradoxa by Grafting," Agroforestry Systems, Vol. 60, No. 1, 2004, pp. 93-99.

doi:10.1023/B:AGFO.0000009408.03728.46

[10] J. A. Yidana, "Progress in Developing Technologies to Domesticate the Cultivation of Shea Tree (Vitellaria paradoxa L.) in Ghana," Agricultural and Food Science Journal of Ghana, Vol. 3, 2004, pp. 249-268.

[11] J. Yeboah, S. T. Lower and F. M. Amoah, “The Rooting Performance Shea (Vitellaria paradoxa C.F. Gaertn) Cuttings Leached in Water and Application of Rooting Hormones in Different Media,” Journal of Plant Science, No. 4, 2009, pp. 10-14. doi:10.3923/jps.2009.10.14

[12] P. W. Hackett, "Juvenility, Maturation and Rejuvenation in Woody Plants,” Horticulture Reviews, Vol. 7, No. 109, 1985.

[13] H. T. Hartmann, D. E. Kester, F. T. Davies Jr. and R. L. Geneve, "Plant Propagation: Principles and Practices," 7th Edition, Prentice Hall, Upper Saddle River, 2001.

[14] B. K. Maynard and N. Bassuk, "Etiolation as a Tool for Rooting Cuttings of Difficult-to-Root Woody Plants," Combined Proceedings of International Plant Propagators Society, 1985, pp. 448-495.

[15] N. Amissah and N. Bassuk, "Severe Cutback of Stock Plant Influences Rooting in Shoots of Quercus bicolor and Quercus macrocarp," Combined Proceedings of International Plant Propagators Society, 2005, pp. 436-438.

[16] N. Amissah and N. Bassuk, "Effect of Light and Cutting Age on Rooting in Quercus bicolor, Quercus robur and Quercus macrocarpa Cuttings," Combined Proceedings of the International Plant Propagators Society, 2007, pp. 286-292.

[17] N. Amissah and N. Bassuk, "Cutting Back Stock Plants Promote Adventitious Rooting of Stems of Quercus bicolor and Quercus macrocarp,” Journal of Environmental Horticulture, Vol. 27, No. 3, 2009, pp. 159-165.

[18] E. F. Frolich, "Rooting Guatemalan Avocado Cuttings,” California Avocado Society Yearbook, 1951, pp. 136138.

[19] N. Bassuk and B. Maynard, “Stock Plant Etiolation,” Hortscience, Vol. 22 1987, pp. 749-750.

[20] J. Griffin and N. Bassuk, "Preliminary Progress on the Asexual Propagation of Oaks," Combined proceedings of International Plant Propagation Society, 1996, pp. 487494.

[21] N. Amissah and N. Bassuk, "Clonal Propagation of Quercusspp Using a Container Layering Technique,” Journal of Environmental Horticulture, Vol. 22, No. 2, 2004, pp. 80-84.

[22] M. Dubois, K. A. Gilles, J. K. Hamilton, P. A. Rebers and F. Smith, "Colorimetric Methods for Determination of Sugars and Related Substances,” Journal of Analytical Chemistry, No. 28, 1956, pp. 350-356. doi:10.1021/ac60111a017 
[23] T. Swain and W. E. Hillis, "The Phenolic Constituents of Prunus domestica," Journal of the Science of Food and Agriculture, Vol. 10, No. 1, 1959, pp. 63-68. doi:10.1002/jsfa. 2740100110

[24] A. Henrique, E. N. Campinhos, E. O. Ono and S. Z. Pinho, "Effect of Plant Growth Regulators in the Rooting of Pinus Cuttings," Brazilian Archives of Biology and
Technology, Vol. 49, No. 2, 2006, pp. 189-196. doi:10.1590/S1516-89132006000300002

[25] J. B. Coll, G. N. Rodrigo, B. S. Garcia and R. S. Tames, “Acido Abscisicoytros Inhibidores,” In: J. B. Coll, G. N. Rodrigo, B. S. Garcia and R. S. Tames, Eds., Fisiologia Vegetal, Madrid, 2002, pp. 369-379. 